\title{
Perceptions of Staffriding in Post-Apartheid South Africa: The Lethal Thrill of Speed or the Masculine Performance of a Painful Past?
}

\section{Dimakatso Sedite}

University of South Africa

\author{
Brett Bowman \\ University of the Witwatersrand

\section{Lindsay Clowes} \\ University of the Western Cape
}

Address correspondence to Dimakatso Sedite, Save the Children, PO Box 14038, Hatfield, 0028, Pretoria, South Africa;

Saffriding, or train surfing, involves taking life threatening physical risks by moving around the outside of moving trains. In aiming to better understand this risky practice, this small scale qualitative study used three semi-structured interviews and three focus discussions to understand perceptions of train surfing in South Africa's Gauteng province. Semi-structured interviews comprised general station staff $(\mathrm{n}=2)$, and a station manager $(n=1)$. The first two focus group discussions held were with ticket marshals $(n=$ 6 per group, with a total of 12), and the last focus group discussion was with commuters $(n=4)$, security personnel $(n=6)$, and a station manager $(n=1)$. Findings revealed that the majority of staffriders were perceived to be young, urban, black boys/men attending suburban schools. Tracing these identity co-ordinates against possible configurations of masculinity, we argue that train surfing represents a particular performance of risky, heteronormative masculinity forged within and against the historical, political and economic legacies that contoured apartheid versions of black' manhood.

Keywords: Masculinities, risk-taking, gender, train surfing, patriarchy, race, performativity, railway injury, staffriding, urban transport

A recent newspaper article reads thus: A 15-year old died while train surfing in Kempton Park on Wednesday morning. He was flung from a moving train ... The teenager sustained possible head injuries, broken bones and internal injuries. He was pronounced dead on the scene. (Independent Newspapers Online, 2010).

Railway commuting is considered to be one of the safest modes of transport in high income countries. However, studies in South Africa show that train transportation is characterized by a considerably high rate of injuries and death, and what has be-come known as train surfing certainly contributes to these statistics (Lerer \& Matzopoulos, 1996). Train surfing entails boarding or disembarking a fast moving train (Lerer \& Matzopoulos, 1996), riding on the exterior of a train that is travelling at high speed (Straucha, Wirthb, \& Gersericka, 1998), or riding on the roof of a moving train (Sternick, Gomes, Serra, Radwanski, \& Pitanguy, 2000). The practice contributes to high railway injury and mortality rates in Germany (Knecht, 1996; Straucha, Wirthb, \& Gersericka, 
1998), Brazil (Sternick, Gomes, Serra, Radwanski, \& Pitanguy, 2000; The Wall Street J ournal, 1988), as well as in South Africa (Lerer \& Matzopoulos, 1996).

\section{Ruling Masculinity}

Epidemiological studies on train surfing in South Africa identifies it as a predominantly young, urban male practice. Only Hesselink's (2008) qualitative study on train surfers in Gauteng provides interview-based accounts of the experiences of train surfers themselves. In a country that has explicitly identified the expansion of its commuter rail networks as a developmental priority, Hesselink's study is important in that it foregrounds the criminological drivers and legal implications of train surfing. Our study, grounded in a different disciplinary and more critical theoretical orientation that foregrounds performativity and the social construction of masculinity, aims to add to this growing body of work.

Drawing on insights emerging out of local and international theorizing around masculinities, our approach is built upon an understanding that gender (and gendered subjectivities) are socially constructed (Carrigan, Connell, \& Lee, 1985; Connell, 1995; Kimmel \& Messner, 2004). Recognising that masculinities are socially constructed requires recognizing the changing social contexts from which they emerge. In highlighting these social contexts we draw on the now substantial body of work of local theorists, in particular the work of Ratele $(2008,2006)$ who offers the concept of 'ruling masculinity' as a useful analytic 'tool' in understanding some of the critical factors that underpin the risky behaviours employed by so many South African men. Seemingly heavily influenced by the well established construct of hegemonic masculinity but more sensitive to local conditions of power, Ratele's (2008, p. 21) ruling masculinity "seeks to en- capsulate and emphasise how the specificities of highly inequitable economic relations, political arrangements, culturally embedded relations and colonial histories observable in societies such as South Africa shape how men behave, think and relate to others." These relationships, expressed as performances of masculinity, can only be understood through recognizing the centrality of historically and socially produced power inequalities built around class and race as well as sexuality, ethnicity, religion and so on. Sexuality in particular has been increasingly understood as central to performances of gender (Arnfred, 2004; Ferber, 1999; Reid \& Walker, 2005). As Shefer et al. (2007, p. 3) have noted in their review of recent work on masculinities "there is pressure on all males, young and old, to conform to the prevailing dominant mode of masculinity. Two key elements are heterosexuality and fearlessness or risk taking". In this study we draw on the insights outlined above to suggest that train surfing is read by other train users as a performance of heteronormative masculinity and that risk taking is central to that performance.

\section{The Train in South Africa's History}

More than simply a mode of transport, trains are invested with a variety of gendered, raced and classed meanings generated out of the social, economic and political roles played by the railways in racist processes of urbanization and industrialization in South African history. The mineral discoveries of the late nineteenth century witnessed an increasing demand for black male labour and this labour was transported to and from the mines by the railways. At the turn of the twentieth century, the Native Land Act of 1913 was another measure aimed at reducing the opportunities open to rural black men, pushing more and more off the land away from their families and into the urban mines (Parnell, 1993). After the election of the Nationalist government in 1948, trains were also employed to help implement the Group Areas Act (1957) to forcibly remove communities de- fined along racial lines by the apartheid government, and both Orcutt (2003) and Pirie (1992)

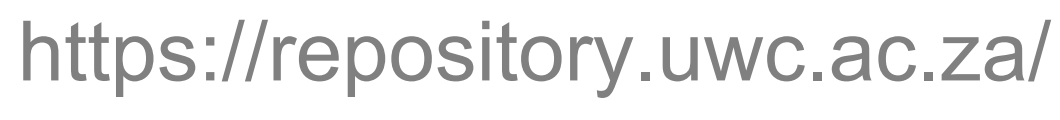


have identified the train as a political site in this period. This is best epitomized in the lyrics of Miriam Makeba's song Mbombela. Mbombela was the name given to a train that transported mineworkers away from their families to their places of work in the cities (Gina, 2003; Lekoba, 2003). The song articulates the sadness in the hearts of the mineworkers waiting for the Mbombela to take them away from their loved ones. And yet at the same time, as noted by Matzopoulos and Lerer (1988), trains served to connect geographically-alienated and racially segregated black South Africans, and these sentiments were expressed by other songs. Looking forward to returning home, tired men (and a few women) would urge the train to hurry up by singing songs like Shosholoza:

Shosholoza, kule'zontaba, stimela si phum'eSouth Africa.

Wen'uyabaleka,

Wen'uyabaleka kule zontaba,

stimela siphum'eSouth Africa. (Move forward and make way on those mountains

The train from South Africa.

You are running away you are running away on those mountains

The train from South Africa.)

More recently, over the course of the 1980s and 1990s, the train has emerged as a symbol of political conflict between two major black political groups (Matzopoulos \& Lerer, 1998; Orcutt, 2003), where the apparently restrained anger and frustration 'sung-away' in earlier times began to be expressed in what has been labeled 'black-on-black' violence.

According to Matzopoulos and Lerer, (1998) it was the spill-over of this violence that helped contribute to the development of the minibus taxi industry in the black townships in the last decades of the twentieth century. And while the shift to a new democratic dispensation after 1994 has seen new meanings begin to attach themselves to trains and railways, these meanings remain gendered, classed and raced. For instance, Matzopoulos and Lerer (1998) have suggested that the collapse of the apartheid regime has seen many displaced urban, black men and women return to the cities where they occupy land informally. Connected to the need to get to and from places of work, the proximity of many of these informal dwellings to the railway lines has resulted in many serious injuries. Use of the urban railway system continues to be highly racialised with black, blue-collar workers making up the overwhelming bulk of its client base (Seekings, 2008). Overall, the rail network infrastructure is underdeveloped and inefficient, with services frequently interrupted. The frustration experienced by passengers occasionally spills over into public violence expressed at times through the torching of railway carriages. It is this gendered, raced and classed history that needs to be taken into account when exploring the contemporary phenomenon of train surfing. This paper suggests that staffriding is one expression of the struggle for gendered personhood and meaning within the tensions and instabilities that contour the map for being a 'post-apartheid black man'. Staffriding is a performance of gen- der and race and class as well as other subjectivities built around age and urban residence. The stage on which this performance takes place is the moving train which itself is loaded with gendered, raced and classed meanings as outlined above.

Train surfers. In South Africa there are various kinds of train surfing - commonly termed staffriding. The most popular type in South African urban trains is sparapara. This is a distinct form of staffriding which entails tap-dancing on and off a train that is in full speed or 'in heat', by young men usually en route to or from school. Whilst this is happening, the women in the train ululate. At the same time boys and young men interfere with the hinges of the automatically operating doors to keep the sliding doors open whilst

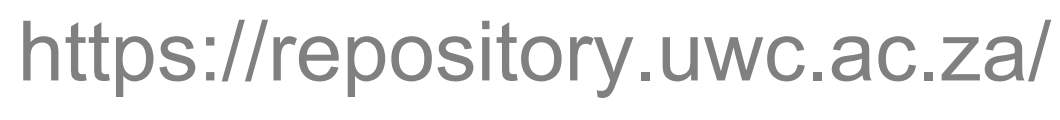


their friends do the sparapara. The name sparapara is derived from the sound that the tapping makes on the platform and train floor. However, according to Kgeledi (2010), there are other kinds of train surfing in South Africa which entail, for example, putting one leg underneath the train and balancing by curling another leg on a metal rod in the middle of the train door; doing the moonwalk on the platform floor; or playing tennis or soccer on the train roof, whilst attaching a rubber band to a tennis ball, to keep it from falling. When the electrical cables approach, train surfers duck or lie down and then continue.

Several motivating factors and correlates have been offered in accounting for train surfing, including individual dispositions such as boredom, thrill-seeking (Straucha, Wirthb \& Gersericka, 1998), a sense of hopelessness and machismo (Cohen, 1988), and rebelliousness (Lerer \& Matzopoulos, 1996); as well as structural facilitators such as a lack of leisure activities amongst the poor (Robertson, 1994). Few analyses however foreground gender and the complex intersections of gender with race, class and age. Most train surfers are between the ages of 10 and 22 years old and are residents in povertystricken, overcrowded neighbourhoods (Cohen, 1988). Other more environmentallyrelated factors have been identified as correlates to the practice. These include warmer temperatures (Straucha et al., 1998) and peak traveller times (Cohen, 1988). The structural designs of older trains also make them amenable to train surfing (Straucha et al., 1998). There is also evidence of concomitant alcohol and substance abuse (Cohen, 1988; Straucha et al., 1998) amongst train surfers.

\section{South African Masculinities and Staffriding}

A substantial body of work on South African masculinities has emerged since the 1990s, with a wide range of contributions from traditional disciplines such as history and psychology, as well as more interdisciplinary and multidisciplinary studies ( Morrell, 2001; Reid \& Walker, 2005; Richter \& Morrell, 2006; Shefer et al., 2007). Central to most of these studies is an understanding of masculinity as relational and performative, as mediated by and co-constituted by other forms of subjectivity such as race, class, sexuality and ethnicity. Many of these studies, as Shefer et al.. (2007) have noted, tend to ask questions about the ways in which patriarchal privileges work to disempower women. In such analyses, men are generally constructed as benefitting from gender inequalities, as privileged oppressors, as perpetrators of violence rather than victims. It is however becoming increasingly clear that gender inequalities are harmful to men as well as women. As Ira Horowitz said, as far back as 1997:

When the lives men lead are examined closely ... it becomes obvious that by trying to follow the roles proscribed for us by our socialization, we suffer serious physical, psychological and emotional harm. As a result, we live very pressured lives and, on average, die younger than women; we spend much of our lives feeling like failures and, because we cannot express those feelings, we often numb them out with alcohol and drugs (Horowitz, 1997, p. 75).

Influence of patriarchy. Hearn (2007) has also noted rather more pithily: "Patriarchy, or patriarchies, is not only bad news for women, but also in different ways for many boys and men" (2007, p. 17). There is, for example, increasing evidence that it is young men, across a variety of contexts, who are the predominant victims of male violence (Altbeker, 2006; Krug, Dahlberg, Mercy, Zwi, \& Lozano, 2002; Norman, Matzopoulos, Groenewald, \& Bradshaw, 2007; Pelser, 2008), and recent studies have begun to explore some of the ways in which gen- der inequalities intersect with other salient

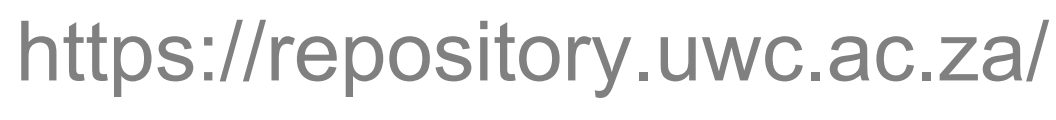


subjectivities to make men vulnerable to harm. Several analysts have suggested that an understanding of gendered subjectivities in the South African past is central to understanding the ways in which contemporary South African men come to harm. It has been suggested that the anti-apartheid struggle generated a context against which young black masculinity formed a core and that this can no longer hold in the void of a negotiated settlement (Cock, 1993; Morrell, 2001; Ratele, 1998; Ratele, 2002; Xaba, 2001). And if versions of masculinity built around race are unsettled, so high rates of poverty and unemployment mean that masculinities built around class, access to resources and the role of economic provider are also increasingly stressed (Ratele, 2002; Silberschmidt, 2004; Walker, 2005). Older forms of Black masculinity were also seemingly propped up by the inequities of formalised and legislated patriarchy. However, these forms of institutionalised

(hetero)patriarchy have themselves been shifted by the sweeping constitutional changes that have enshrined gender equality as a fundamental feature of post-apartheid South Africa. (Epstein, 1998; Motsemme, 2002; Ratele, 1998; Walker, 2005). On the one hand then, dominant masculinities have been unsettled by the social, economic and political changes since 1994. On the other, hegemonic masculinities continue to be associated with risk-taking and risky behaviour, risk to the self as well as other men, women and children (Hearn, 2007, p. 31).

Risk-taking behavior. Risk-taking, heterosexual prowess and being a patriarch or father seem to be relatively universal elements of contemporary masculinities, although as Shefer et al. (2007, p. 3) have noted, these "apparent commonalities are nuanced and shaped by the particular context in which they appear." Certainly local research suggests that heterosexualised risk-taking is common in local contexts. Research on sexuality and HIV highlights the ways in which sex with multiple partners has become normative for men ( Campbell, 2001; Hunter, 2005) as well as pointing to the tensions experienced by young men who resist hegemonic (hetero) masculinities by taking just one rather than multiple sexual partners (Lindegger \& Maxwell, 2007). But whether overtly sexual or not, risky practices are fur- ther facilitated by substance abuse and violence that in turn increase the likelihood that men's bodies will come to harm (Clowes et al., in press; Gmel et al. 2009; Harrison, 2005; Lazarus et al., 2008). Such is the magnitude of masculinised risk-taking that in South Africa (a country in which males and females make up equal proportions of the population) that for every one female victim of non-natural death, there are approximately four males (Prinsloo, 2007).

\section{Goals of the Study}

This article attempts to illustrate the importance of under- standing such risky behavior in social, economic and historical context (Diez-Roux, 1998). We suggest in this paper that train surfing needs to be understood as an example of risk-taking that can be better understood if local histories and contemporary conditions are used to bring context back into descriptions of risk and death-defying performances. Specifically, the study was concerned with the particular socio-historical dimensions that are perceived to shape staffriding as a high-risk activity. This general focus was guided by questions such as: why do some passengers staffride? How is this high-risk activity understood by other passengers and other rail commuter stake- holders?

\section{Method}

\section{Participants and Setting}

Within the confines of a small scale qualitative study the study employed a convenience sample to recruit as wide a range of train users and authorities as possible.

\section{https://repository.uwc.ac.za/}


The first author held three interviews with one male station manager and two male general train staff. She also held three focus group discussions, with the first two focus group sessions comprising a total of 12 ticket marshals (10 male and 2 female). The third focus group discussion was held with 4 commuters (2 male, 2 female), 6 security personnel (3 male, 3 female), as well as one station manager (male).

\section{Data Collection}

The data obtained from three focus groups was complemented by three semi structured interviews that explored in more detail some of the issues raised by the focus groups. The semi-structured interview and focus group schedule included questions and probes designed to elicit the interviewees and groups' perceptions on the causes and consequences of staffriding and the meanings attached to this high-risk activity from a variety of perspectives. The transcripts were reviewed and coded by two independent raters and the credibility and trustworthiness of both the data and interpretations thereof were assessed for rigour in accordance with the guidelines offered by Lincoln \& Guba (1985).

\section{Procedure}

After obtaining written consent from the train authorities to conduct this research, information sheets explaining the aim of the study were distributed to potential participants at three stations in Gauteng province. The research was conducted ethically via an Informed Consent agreement that explained that participation was voluntary, that participants could freely withdraw from the study at any time and that guaranteed confidentiality and anonymity. Those who gave consent were scheduled either for a focus group discussion or for a semi structured inter- view all of which were conducted by the first author over the course of three days.

\section{Data Analysis}

The data generated from each of these sessions were transcribed verbatim, forming the corpus for analysis. The corpus was subjected to thematic content analysis under the frame work provided by Graneheim and Lundman (2003) and assessed for methodological rigour against the guidelines and criteria provided by Lincoln \& Guba (1985).

\section{Results and Discussion}

Thematic content analysis of the corpus yielded four primary themes. These were staffriding as a rite of passage for young urban boys, staffriding as a challenge to adult and state authority, class, socio-economic context and masculinity and staffriding as performance of masculinity. Underpinning the analysis that yielded these themes is an understanding of the body "as an instrument or vehicle through which sets of meaning and ways of being in the world are negotiated" (Gqola, 2007, p. 150), suggesting that train surfing can be understood as a demonstration of physical prowess and autonomy aimed at signifying adult heterosexual manhood in a specific context. Thus we begin with a discussion of how train surfing can be under- stood as a rite of passage, as a public display of young urban heterosexual masculinity. Intimately connected to this is the second discussion where we explore intergenerational gendered conflict whereby train surfing is understood as embodying a series of challenges to the authority of older men. The physical location of these challenges is the focus of the third discussion where we suggest that class and socio-economic context are important in making sense of train surfing. Finally, we explore how in this context performances of masculinity are key in understanding the practice of staffriding and that gender, youth, class, and race operate together to produce the popularity of such risky performances for young urban working class black masculinities. 
Without exception all of the participants indicated that staffriding is practised exclusively by male school-going youth between 12 and 18 years of age. Many of the participants believed that this age is particularly vulnerable to a need for peer acceptance. Because staffriding is a risky, competitive behaviour which requires a demonstration of physical agility, adeptness and bravery, the respondents attributed the practice to a form of 'rite of passage' through which boys could distance themselves from their mothers. They perceived it to align them with men, through a bodily practice through which they would be considered men by the commuters on the train.

Sparapara is done mostly by schoolchildren in order to show off to the others how cool they are... they want to prove they are not mama's babies (Participant 1, focus group 3).

The practice is not however a 'once off' ritual it is practiced daily. Even after constant reprimands and threats by predominantly male safety officials on the trains, the boys reportedly persist with their staffriding.

After apprehending them, they rebuke them, then they take down their names. Tomorrow they do the same with the others, because they are many (Participant 4, focus group 2).

Staffriding is also not perceived simply as part of routine travel between destinations. Rather it is seen as an activity, an end in itself.

And after school, they take their bags home, and change clothes, and then it's back to sparapara! They go back and forth between $\mathrm{E}$ and $\mathrm{M}, \mathrm{E}$ and $\mathrm{M}, \mathrm{E}$ and $\mathrm{M}$ (Participant 4, focus group 2).

While a range of epidemiological studies in South Africa haveargued that this age group and gender are a 'risk group' for violence, traffic injuries and substance abuse (Ratele, 2008), it is important to understand this 'risk in context'. For example, urban South African life is itself 'risky' for many and thus presents young men with a variety of possibilities for risky practices. In staffriding, these young men 'choose' a variety of risks. These young men choose to risk their lives and limbs in the physical challenge embodied by staffriding, and other practices at the station that endanger their lives.

They like it here [at the station], they even bring their bikes to spin around these stairway rails, some do fall (Particpant 5, focus group 2)

Some do fall [off the rails]. When he has fallen, they [friends] say he is bari, a moegoe (an idiot) (Participant 6, focus group 2)

They choose to endanger themselves repeatedly. The positive meanings attributed to the practice of endangerment embodied in staffriding by other boys and girls clearly outweigh the physical risks and we suggest this has to do with attempts to demonstrate masculinity to other boys and men through physical prowess and ability. While the specifics differ from culture to culture the taking of risks, particularly in front of other young men, has been associated with steps towards adult manhood as Gqola (2007) has observed of traditional practices such as Ulwaluko in isiXhosa communities.

In adults, sparapara is very rare, when an adult does sparapara, it is when he is rushing for a train to ensure that he does not miss it, and what will happen is that he will run for it. But children do it out of fun, in other words, they enjoy what they are doing, they want to show their peers that they can out-perform them (Participant 1, focus group 3).

While apartheid legacies of racist, capitalist urbanisation and industrialisation have undermined or distorted the possibilities around employing traditional cultural practices

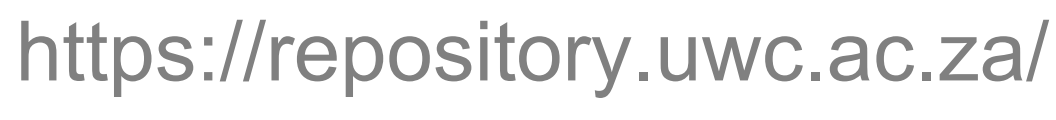


involved in becoming a man, they have simultaneously presented new opportunities. In building on the historic meanings embodied by trains, we suggest that train surfing offers new ways of inscribing masculinity on male bodies in contemporary urban contexts.

\section{Staffriding as a Challenge to Adult and State Authority}

The large number of schoolchildren commuting to suburban schools by trains means that even young children have the freedom to travel without parental guidance and proper supervision. But while young women and girls seem to be able to manage this without challenging the male officials on the train, many young men and boys reportedly engage in deliberate confrontations with older men in positions of authority:

When you say to him 'Get away from that door' He retorts You can't tell me anything, you...Who the hell are you!' Of course, you end up not saying anything at all (Participant 6, focus group 3).

They want a place where they can break the law; otherwise they do not feel OK. If our law in the country was tight and we had enough places for holding in custody those who break thelaw, I think they would learn a lesson (Interview 1).

One time one man tried to staffride and I tried to stop him, but he still did it. Then he fell, I then asked him why he did it and he told me "It's got nothing to do with you". So people do not even care about their own lives, so they are saying “Why should you?" It has to do with lawlessness in society in general, no respect for life (Interview 3).

Intergenerational learning. Intergenerational conflicts between men in diverse social and historical contexts have been recorded by a number of analysts (Carton, 2001; McClendon, 2002; McKittrick, 2002; ). However while such challenges may be relatively universal, the historical specificities of such challenges impact and shape the local meanings ascribed to them. In South Africa contemporary intergenerational challenges have their roots in the history of apartheid where challenges to the racist and gendered legislation of the apartheid state were part and parcel of daily life in the second half of the twentieth century (Epstein, 1998; Ratele, 1998). In consolidating and tightening up earlier legislation that privileged white South Africans, apartheid reinforced and entrenched the criminalization of the most mundane events and practices in the lives of black South Africans. A 'pass' was required to be in an urban area for example, while without the right paperwork simply living together as husband and wife was illegal. While experiences of apartheid were mediated by gender and class as well as other signifiers of subjectivity, it was black male bodies that made up the bulk of those incarcerated in apartheid prisons, and who made up the bulk of those in positions of political leadership in anti-apartheid struggles. The history of apartheid has thus meant that an encounter with the forces of apartheid law and order have generally been understood to be a source of masculine pride rather than a source of stigma. More specifically, transgression against the authority of the state relayed through explicitly defying the orders of 'elders' has a long history in South African masculinity. We suggest that staff riding needs to be understood within this history of defiance.

Substance abuse. Part of the challenge laid down by young male staffriders to the older male authorities charged with running the trains was the public abuse of substances such as dagga (marijuana). As Shefer et al. (2007, p. 3) have noted "expectations of young males have thus traditionally tended to demand that they take all manner of risks, specifically sexual and mortal risk, but also risks related to smoking, using other drugs and substances, and engaging in sexually abusive and other violent behaviours".

What I wanted to say was that with this staffriding, children start it in the morning,

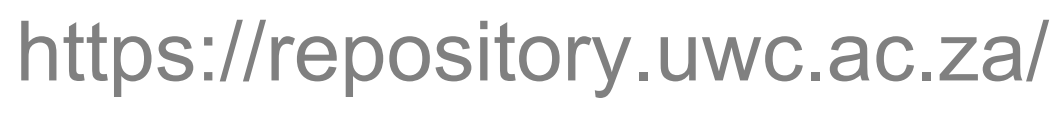


and then we think that (incoherent).. because they board one coach in the morning, during peak time they board that one coach again, and then they smoke dagga inside that one coach (Participant 3, focus group 3).

You cannot do sparapara without having smoked dagga...That is a serious problem (Participant 3, focus group 3).

But we have a main problem in that in the morning they smoke dagga at the end of the platform, and then it is difficult for us to move from here at the verification point and go to them (Participant 9, focus group 3).

While there is inconsistent evidence regarding cannabis as a risk factor for injury (Gmel, 2009), the point here is that staffriders' challenges to patriarchal and state authorities are multi-axial and public and their challenges are implicitly reinforced by the apparent absence of any restraining influence on the part of parents. When train surfers are apprehended their parents are contacted but are reported not to attend the various fora aimed at generating awareness of the dangers inherent in the practice. In fact, one participant emphasised that parents were generally invisible.

When the parents hear the words "commuter meeting", during the councillor meetings, they will eat you with their teeth! I'm sure you have witnessed that we have erected too many tents here. One day the tent had to be returned because the parents did not come attend the meeting. So, I do not know which strategy we can use to make parents attend themeeting (Participant 1, focus group 3).

In cases where parents do respond to calls to account for their boys' apparent lawlessness they are apparently quick to identify the problem within the railway infrastructure and the practices of the train authorities and administrators rather than understanding such tragedies as intimately connected to normative practices around risky performances of masculinity.

Er, it is true that parents do not believe it when their child has been killed during sparapara. They blame the train company. Since working here I have never heard a parent accepting that her child staffrides, they always say ‘No, no, no, it is [the station's] fault (Participant 2, focus group 3)

In ascribing blame to the railway infrastructure/ station this utterance leads us to our third discussion where we explore the significance of class and socio-economic context in contributing to train surfing.

\section{Class, Socio-economic Context and Masculinity}

While the history of the train in South Africa has always implicated 'race' and class in the various ways in which different carriages were assigned to different 'races' and classes (Pirie, 1992) as a function of a highly racialised urban spatial environment, in postapartheid South Africa the use of conventional railway services has come to be seen as a marker of class status. This is unsurprising given that apartheid's segregated urban planning necessitated racially stratified access to mobility and transport (Donaldson, 2006). In 1997, the United Nations Centre for Human Settlements reported that 90 percent of Whites and only 11 percent of 'Blacks' owned motor vehicles. One year later, de Saint-Laurent (1998) observed that the developed suburban landscapes of South Africa almost demanded car ownership while in the poorer areas, the main modes of transport were buses, mini-buses, taxis, trains or walking on foot. More recently, Walters reports that in 2007, 84 percent of rail users were 'Black' and 'In socio-economic terms, rail users are amongst the lowest income groups and least able to exercise modal

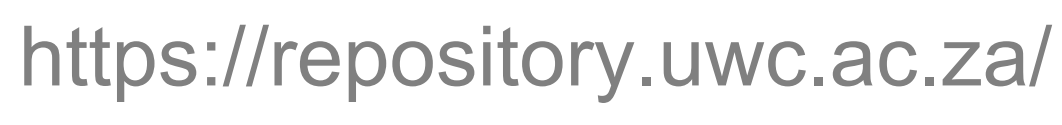


choice. Access to the rail system, punctuality and security at stations and on trains are the main concerns of users and potential users, resulting in a declining market share of $14 \%$ compared to the other modes of public transport (bus and taxi) (Walters, 2008, p. 104). Lack of investment over the past 10 - 15 years has resulted in unsafe trains and poor station security.

Against this backdrop it is easy to make sense of participant 2's suggestions above. Firstly, that the injuries and deaths resulting from staffriding are understood to be the fault of the railway authorities and those charged with managing rail services. In this, the participant is not alone as several participants made similar comments, arguing that a lack of security infrastructure, problems in service delivery and broken or damaged trains served to enable staffriding. "The reason [staffriding takes place] is that people are avoiding overcrowding, however, I sympathise with them" (P1, inter- view 1). Others suggested that staffriding takes place because "sometimes train doors are damaged, because they force the doors open" (P3, interview 3) or because there are understood to be too few security guards:

If [the authorities] can place security personnel to guard these children when they board the trains...without the security personnel on every coach, nothing will come right! (Participant 4, focus group 3).

I am appealing to us as parents as well as commuters, to send the message to the CEO that we need guards, securities in each coach. Every single train used to have ten guards, the company must pay them and that thing [sparapara] can stop, because you know whose problem this is? It is the company's problem (Participant 2, focus group 3).

In other words it is socio-economic context and class that matters here. On the one hand it is specifically working class South Africans who are forced to use public transport in the absence of the resources to make alternative choices. On the other hand these participants are also drawing attention to what they see as inadequate resourcing of public transport in the form of railways and the ways in which this compromises the safety and security of working class South Africans. A second and related point emerging out of several of the extracts above is the clear distancing of participants from 'the problem'. Placing limits on the behaviours of these young men is not understood as the task of commuters (or even parents as discussed earlier), it is clearly framed as the problem of an absent other - security guards most of whom could be imagined as men supplied by railway authorities. In contexts where the traditional checks and balances tying communities together have been systematically undermined by apartheid legislation and further weakened by racist and capitalist industrialization while simultaneously being dislocated by urbanization, informal systems of social control are compromised (Glaser, 1998). In addition, the insistence on referring to a staffrider as a 'child' or as 'children', or as 'people' is revealing and leads into our next discussion That staffriding is a performance of masculinity is completely concealed in such extracts, and yet, as we discuss below, it is performances of masculinity that lie at the heart of staffriding.

\section{Staffriding as Performance of Masculinity}

Whether or not participants saw staffriders as boys, children or men, all of them recognized that staffriding was a public performance aimed primarily at other young men and women, but also at the older men and women who were on the trains either as employees or as commuters:

Staffriding is always done in order to entertain others. To show off to the girls

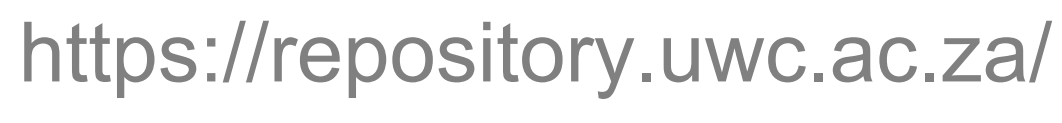


and friends...When someone does staffriding, they ululate...They ululate, yes! When their friend plays staffriding, they go crazy (, Interview 1).

Performances of staffriding can be understood as an ex- pression of successful masculinity. One participant noted that "they see trains are places for klevas, the cool ones. If you do not do sparapara, you are not cool." When the inter- viewer responded by asking "Oh, you cannot be a boy who commutes in a train and not know sparapara?" there was a resounding "Uhuh!" of agreement from the rest of the group (Participant, focus group 4).

Participants also noted that the response of the female audience was important in understanding why young men engaged in staffriding. In other words staffriding needs to be understood as an expression of heterosexual masculinity. Some participants insisted that women rewarded the behaviour through ululating - public recognition by women of men. Others suggest that when a young man falls and injures himself, women down- play the tragedy; a young man's failure to perform staffriding (read masculinity) successfully is minimized as the following ex- tract reveals:

If the staffrider accidentally slips underneath the train and gets injured or dies, the women would express disappointment at his lack of adeptness by saying "Ai, son-in-law, you played badly...you should have entered through the window, not underneath", with a low, albeit casual, and amused tone of voice (P4, interview 4).

Staffriding can be understood as a 'conversation' between young, urban, black, heterosexual men. As noted earlier the young men who engage in staffriding are perceived to be the "klevas, the cool ones." This further strengthens the argument made above that staffriding is in effect a rite of passage necessary for a young boy to be included in the group as a man. And when one of the group gets hurt or injured another performance of appropriate masculinity is to dismiss it, to conceal any emotional distress being witness to the pain and suffering of a friend may have caused:

P1: [B]ecause even when one of their friends dies whilst staffriding, they say he fumbles, that he did not know how to staffride, that he was bluffing (Wa se phaphela).

R: The friends do not feel hurt?

P1: No! "He did not know how to staffride, he was merely bluffing. He should have come to us and we would have taught him the ropes".

$\mathrm{R}$ : You mean the friends do not feel regret or pain?

P1: No, "He (the victim) did not really know staffriding. He was just bluffing. He did not know staffriding, he was bluff- ing. He should have come to us, the boys, we would have taught him".

R: They do not feel guilt nor do they learn a lesson from the fate of their friend?

P: No, no, no. They say he was bluffing, he did not know how to staffride, that is why he was dead. They say he could not staffride that is why he was dead. Because he could not staffride.

R: And then they continue to staffride...

P1: They continue! Because they can staffride, he died be cause he could not.

R: Are they not afraid to die?

P1: No. According to them, they know how to staffride, so they cannot die. They tell themselves that they know how to staffride, so they cannot die. (Interview 1).

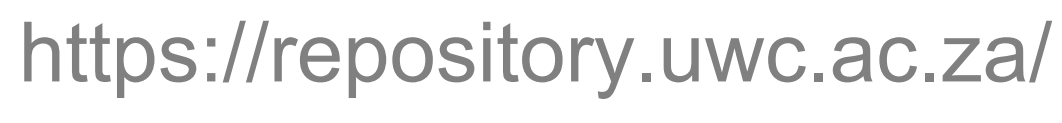


The above extract perhaps exemplifies most poignantly the links between performances of masculinity and staffriding. In the view of this participant, a staffrider who falls to injury or death is constructed as a failed or spurious man by other men. For these 'other' men, mastering and completing a successful staffride comes to represent the coordinates of 'successful' manhood while bluffing' or pretending to have achieved such mastery over a potentially fatal practice is greeted with unrepentant disapproval. Moreover, in this exchange successful staffriding is patently linked to invincibility as if urban young men construct surviving risk as a powerful marker of manhood. Ratele's (2008) insights into the relationship between male mortality and risk are invaluable for reading this exchange. This participant suggests that when faced with the death of a friend who 'fails' to perform the collective vision of 'being a man', the injunction to invisibilise the historical, social and economic realities that shape this performance is so great that staffriding and masculinity become tightly fused in a logic that ties death to emasculation and immortality to a mastery of hegemonic masculinity.

\section{Conclusion}

In South Africa, staffriders are predominantly young, urban, poor, black men. Various theorists of masculinities and public health researchers in South Africa have pointed to the imperative to use these terms as proxies of the political sort ( Bowman, Burrows, Seedat \& Duncan, 2006; Ratele, 1998; Shefer, Ratele, Strebel, Shabalala, \& Buikema, 2007) when considering 'at-risk' groups in the country. Our analysis of staffriding has in some ways attempted to surface some of the very many ways in which we may be able to map these proxies onto very specific conditions anchored in the history, economics, space and racialised identity politics that make up the social fabric of contemporary urban South Africa. We have attempted to show that the practice of staffriding represents a contemporary site in which each of these coordinates animates the performance of South African ruling masculinity. As such, we should not under- stand the moment of the dangerous boarding of the train or the impromptu performance of the sparapara, as a lethal thrill fueled by the 'essential' ingredient of manhood - a boys will be boys' type of response. Instead, we need to understand staffriding as a performance representing the confluence of subjectivities built around (and co-constituted by) gender, race, class, and age, as well as urban residence. Each of these axes of power needs to be understood as mediating the others and as sets of tensions, alignments, resistances and negotiations that produce the gendered person in particular contexts. To this end, we offer some tentative suggestions for understanding staffriding as an historical, social and political practice.

Although staffriding is an old phenomenon in South Africa, it seems to have enjoyed greater visibility as a public health issue in post-apartheid South Africa. The influx of township children to suburban schools seems to be a primary reason for this rise. The post-apartheid space presents very real challenges for 'blackness' and 'maleness'. Both Gray (1994) and Ratele (1998) make a convincing case for a significant part of South African black male identity' being historically defined through the prism of the defiance of white racism for so long such that the absence of institutional 'white power' leaves a void around which to construct a masculine identity. Given the history of the train as an instrument of apartheid control and its positioning as the vehicle of the post-apartheid underclass and the trains as a liminal space, staffriding may be a performance of young urban black masculinity in the limbo that separates one platform from another on the railway networks that continue to divide poverty from possibility.

Our findings however indicate that the material conditions define both the route and the train. In line with Straucha, Wirthb and Gersericka (1998) we found that the older and more dilapidated train models were perceived to facilitate staffriding. In addition, an

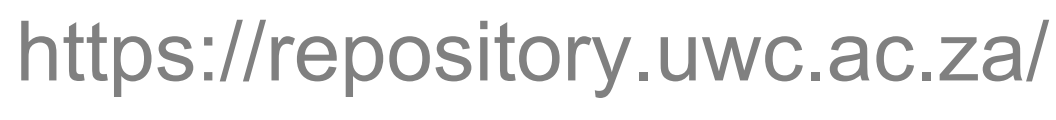


overwhelming increase in the number of urban train-commuters, coupled with the challenges around adequate staffing levels on trains and at stations, has made it difficult to police the practice. Rather than seeing this as a set of factors that needs to be understood and explored outside of the socio-historical and economic analysis of staffriding, these material conditions birthed in apartheid continue to bear down on the practice, providing the material space for a performance of history in the present and the negotiation of black male identity in the liminal time and space of the train.

Given the fact that this study explored the perceptions of key informants in the railway transport sector, none of whom explicitly claimed to have ever been staffriders themselves, our analysis remains speculative at best. However, as staffriding is an extremely risky behavior, it is important to find ways of reducing its incidence. In this paper we have suggested that staffriding needs to be understood as an historically and culturally specific performance of masculinity. New lines of research on staffriding in South Africa would thus benefit from integrating some of our tentative interpretations in the formulation of data collection instruments that could then be used to explore in more detail some of the ways in which staffriders themselves understand their practice. While our study is limited in that it has not explored the views of staffriders themselves, if we understand staffriding as a performance then the understandings of the var ious audiences of the performance are critical. Thus, our study has gone some way to illustrating the historical, political and economic dimensions that frame safety and risk in the everyday enactment of a seemingly obvious instantiation of modern masculinity on the railway networks of urban South Africa.

\section{References}

Altbeker, A. (2006, November 30). Why is crime in South Africa so uniquely violent? Harold Wolpe Memorial Trust's 55th Open Dialogue. Paper and transcript of discussion.

Arnfred, S. (2004). Re-thinking sexualities in Africa. Stockholm, Sweden: Almqvist \& Wiksell Tryckeri AB.

Bowman, B., Seedat, M., Duncan, N., \& Burrows, S. (2006). 'Race', social transformation and redress in the South African social and health sciences. In G. Stevens, V. Franchi, \&

T. Swart (Eds.), A race against time: Psychology and challenges to deracialisation in

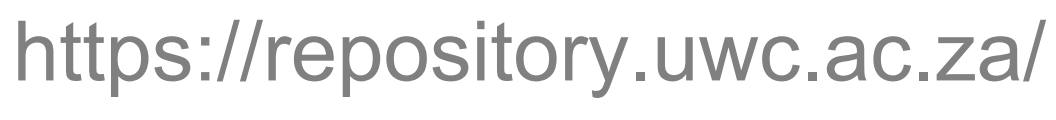


South Africa (pp. 91- 103). Pretoria, South Africa: Unisa Press.

Campbell, C. (2001). Going underground and going after women: Masculinity and HIV transmission amongst black workers on the gold mines. In R. Morrell (Ed.), Changing men in Southern Africa (pp. 286). Pietermaritzburg, South Africa: University of Natal Press.

Carrigan, T., Connell, R. W., \& Lee, J. (1985). Towards a new sociology of masculinity. Theory and Society, 14, 551- 604.

Carton, B. (2001). Locusts fall from the sky: manhood and migrancy in KwaZulu. In R. Morrell (Ed.), Changing men in Southern Africa (pp. 129- 140). Pietermaritzburg, South Africa: University of Natal Press.

Clowes, L., Lazarus, S., \& Ratele, K. (2010). Risk and protective factors to male interpersonal violence: Views of some male university students. African Safety Promotion: A J ournal of Injury and Violence Prevention, 8(1), 1- 19.

Cock, J. (1993). Women and war in South Africa. Cape Town, South Africa: Oxford University Press.

Cohen, R. (1988, November 1). Brazilian youths get macho thrills riding atop trains. The Wall Street Journal. Retrieved February, 23, 2009 from http:// pqasb.pqarchiver.com/wsj/

Connell, R. W. (1995). Masculinities. Berkeley, CA: University of California Press.

de Saint-Laurent, B. (1998, September). Overview of urban transport in South Africa. Paper presented at the Eighth COSATU Conference, Cape Town, South Africa.

Diez-Roux, A. (1998). Bringing context back into epidemiology: variables and fallacies in multilevel analysis. American J ournal of Public Health, 88(2), 216- 222.

Donaldson, M. (1993). What is hegemonic masculinity? Theory and Society, 22(5), 643657.

Donaldson, R. (2006). Mass rapid rail development in South Af- rica's metropolitan core: Towards a new urban form? Land Use Policy, 23(3), 344- 352.

Epstein, D. (1998). Marked men: Whiteness and masculinity. Agenda, 37, 49- 59.

Ferber, A. (1999). White man falling: Race, gender and white supremacy. New York, NY: Rowman \&Littlefield.

Glaser, C. (1998). Swines, hazels and the dirty dozen: Masculinity, territoriality and the youth gangs of Soweto 1960-1976. Journal of Southern African Studies, 24(4), 719736.

Gmel, G., Kuendig, H., Rehm, J., Schreyer, N., \& Daeppen, J . B. (2009). Alcohol and cannabis use as risk factors for injury: A case-crossover analysis in a Swiss hospital emergency department. BMC Public Health, 9(1), 1-9.

Gqola, P. (2007). A woman cannot marry a boy: rescue, specta- cle and transitional Xhosa

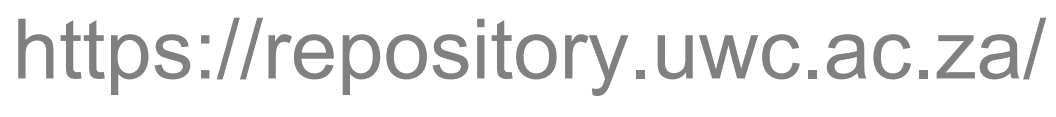


masculinities. In T. Shefer, K. Ratele, A. Strebel, N. Shabalala, \&R. Buikema (Eds.), From boys to men: Social constructions of masculinity in contem- porary society (pp. 145159). Cape Town, South Africa: UCT Press.

Graneheim, U.H., \& Lundman, B. (2003). Qualitative content analysis in nursing research: Concepts, procedures and measures to reach trustworthiness. Nurse Education To- day. 24, 104- 112.

Gray, H. (1994). Black masculinity and visual culture. In http:// muse.jhu.edu/ quick_tour/ 18.2 gray.html. Retrieved on 10 September 2003.

Harrison, A. (2005). Young people and HIV/AIDS in South Af-rica: prevalence of infection, risk factors and social context. In S. S. Abdool Karim \& Q. Abdool Karim (Eds.), HIV/ AIDS in South Africa (pp. 261- 284). Cape Town, South Africa: Cambridge Press.

Hearn, J. (2007). The problems boys and men create, the prob-lems boys and men experience. In T. Shefer, K. Ratele, A. Strebel, N. J . Shabalala, \&R. Buikema (Eds.), From boys tomen: Social constructions of masculinity in contemporary society (pp. 13-32). Landsdowne, South Africa: University of Cape Town Press.

Health-e News (2001). 'SAB forced to pull beer ad'http:// www.healthe.org.za/ news/ article.php?uid=20032834 accessed 01/07/ 2010.

Hesselink, A. (2008). Trainsurfing: A new phenomenon in South Africa? Acta Criminalogica, 1, 117- 130.

Horowitz, I. (1997). Sexism hurts us all. Agenda, 33, 75- 80.

Hunter, M. (2005). Cultural politics and masculinities: multiple partners in historical perspective in KwaZulu-Natal. Culture, Health \& Sexuality, 7(4), 389- 403.

Independent Newspapers Online (IOL) (2010, April) Boy, 15, dies while "train-surfing”. Retrieved June 17, 2010, from http:// www.iol.co.za/index.php?set_id=1\&click_id=13\&art_id= nw20100421112327360C933796.

Kimmel, M.S., \& Messner, M.A. (2004). Men’s lives. Boston, MA: Pearson Education.

Knecht, T. (1996). J oyriding and Dissocial Behaviour. A Comparative Study Based on 24 Members of a Delinquent Group. Archiv Fur Kriminologie, 198 (3/4), 110- 116.

Krippendorff, K. (1980). Content analysis: An Introduction to its methodology. Beverly Hills, CA: Sage.

Krug, E., Dahlberg, L.L., Mercy, J.A., Zwi, A.B., \& Lozano, R. (Eds.). (2002). World report on violence and health. Geneva, Switzerland: World Health Organization.

Lazarus, S., Tonsing, S., Ratele, K., \&van Niekerk, A. (2008).An exploratory study into the risk and protective factors to maleinterpersonal violence. Tygerberg, South Africa: Medical Research Council.

Lerer, L. B., \& Matzopoulos, R. (1996). Meeting the challenge of railway injury in a South African city. The Lancet, 348(9028), 664- 666.

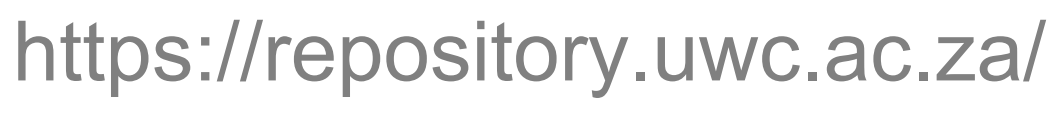


Lincoln, Y., \&Guba, E. G. (1985). Naturalistic Inquiry. Newbury Park, CA: Sage.

Lindeggar, G., \& Maxwell, J . (2007). Teenage masculinity: The double find of conformity to hegemonic standards. In T. Shefer, K. Ratele, A., Strebel, N. Shabalala, \& R. Buikema (Eds.), From boys to men: Social constructions of masculinity in contemporary society (pp. 94- 111). Landsdowne, South Africa: UCT Press.

Matzopoulos, R., \& Lerer, L. B. (1998). Hours to Hell and Back: A social epidemiology of railway injury in a south African city, 1890 to 1995. Social Science and Medicine, $47(1)$,

75- 83.

Mc Clendon, T. (2002). Genders and generations apart: Labor tenants and customary law in segregation era South Africa, 1920s-1940s. Cape Town, South Africa: Heinemann.

McKittrick, M. (2002). To dwell secure: Generation, Christianity, and colonialism in Ovamboland. Portsmouth: Heinemann.

Morrell, R. (Ed.). (2001). Changing men in Southern Africa. Durban, South Africa :Zed/ University of Natal Press.

Motsemme, N. (2002, July). Gendered experiences of blackness in post-apartheid South Africa. Paper presented at the Eighth International Interdisciplinary Congress on Women, Women's World, Makerere University, Kampala, Uganda.

Norman, R., Matzopoulos, R., Groenewald, P., \&Bradshaw, D. (2007). The high burden of injuries in South Africa. Bulletin of the World Health Organization, 85(9), 695- 701.

Orcutt, J . (1997). Transportation struggles in the post-apartheid city. Progressive Planning Magazine. Retrieved September, 15, 2003 from http:// www.plannersnetwork.org/ htm/ pub/ar- chives/ 125/saafrica.htm.

Parnell, S. (1993). Johannesburg slums and racial segregation in cities, 1910-1937 (Unpublished master's thesis). Univer- sity of the Witwatersrand, J ohannesburg, South Africa.

Pelser, E. (2008, May 13). Learning to be lost: Youth crime in South Africa. Discussion paper presented by Centre for Jus- tice and Crime Prevention at the Human Sciences Research Council Youth Policy Initiative, Reserve Bank, Pretoria, Cape Town, South Africa.

Prinsloo, M. (Ed.). (2007). The National Injury Mortality Surveillance System (7th ed.). Retrieved J uly 5, 2010 from http:/ / www.sahealthinfo.org/violence/ national2005.pdf

Pirie, G. H. (1992). Rolling segregation into apartheid: South African railways, 1948-1953. J ournal of Contemporary His- tory, 27(4), 671-693.

Ratele, K. (1998). The end of the black man. Agenda, 37, 60-64.

Ratele, K. (2002). Contradictions in constructions of African masculinity. News from the Nordic Afrika Institute. Retrieved July, 23, 2010 from http:// www.arscr.org/ features/issues005.htm. 
Ratele, K. (2006). Rulingmasculinity and sexuality. Feminist Af- rica 6, 48- 64.

Ratele, K. (2008). Ruling masculinity and mortality in South Af- rica. African Safety Promotion: A J ournal of Injury and Vio- lence Prevention, 6(2), 21- 35.

Reid, G., \& Walker, L. (2005). Masculinities in question. In G. Reid \& L. Walker (Eds.), Men behaving differently (pp. 1-20). Cape Town, South Africa: Double Storey.

Richter, L., \& Morrell, R. (Eds.). (2006). Baba: Men and fatherhood in South Africa. Cape Town, South Africa: HSRC Press.

Robertson, B. (1994). Leisure in the lives of male adolescents who engage in delinquent activity for excitement. J ournal of Park and Recreation Administration, 12(4), 29-46.

Seekings, J. (2008). The continuing salience of race: Discrimination and diversity in South Africa. J ournal of Contempo- rary African Studies, 26(1), 1- 25.

Shefer, T., Ratele, K., Strebel, A., Shabalala, N.J ., \& Buikema, R. (Eds.). (2007). From boys to men: Social constructions of masculinity in contemporary society (pp. 1-12). Landsdowne: University of Cape Town Press.

Silbersmidt, M. (2004). Masculinities, sexuality and socio-economic change in rural and urban East Africa. In S. Arnfred, (Ed.), Re-thinking sexualities in Africa (pp. 233- 250). Stockholm, Sweden: Almqvist \&Wiksell Tryckeri AB.

Sternick, I., Gomes, R. D., Serra, M.C., Radwanski, H.N., \& Pitanguy, I. (2000). Burns, 26(5), 470- 473.

Straucha, H., Wirthb, I., \& Gesericka, G. (1998). Fatal accidents due to train surfing in Berlin. Forensic Science International, 94(1-2), 119- 127.

UNCHS (United Nations Centre for Human Settlements) (1997). Transport and Communications for Urban Development: Report of the Habitat 2 Global workshop, Nairobi, UNCHS.

Walker, L. (2005). Negotiating the boundaries of masculinity in post-apartheid South Africa. In G. Reid \& L. Walker, (Eds.), Men behaving differently (pp. 171- 182). Cape Town, South Africa: Double Storey.

Walters, J . (2008). Overview of public transport policy developments in South Africa. Research in Transportation Economics, 22(1), 98- 108.

Xaba, T. (2001). Masculinity and its malcontents: the confrontation between 'struggle masculinity' and 'post struggle masculinity' (1990-1997). In R. Morrell (Ed.), Changing men in Southern Africa (pp. 105- 124). Pietermaritzburg, South Africa: University of Natal Press.

\section{Endnotes}

1 That men are encouraged to engage in behaviours that put them at risk is underlined by the recent South African Breweries advert (subsequently withdrawn) that juxtaposed a $750 \mathrm{ml}$ bottle of beer alongside a pint and asked "Groot man of laaitie" which translates as "Big man or small boy". http://www.health-e.org.za/news/article.php?uid=20032834

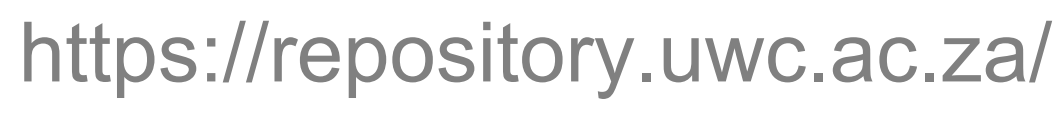


accessed 01/ 07/ 2010.

2 This type of mortality includes deaths due to homicide, suicides, motor-vehicle collisions, burns and drownings 